AISYAH: JURNAL ILMU KESEHATAN 2 (1) 2017, 11 - 16

Available online at http://ejournal.stikesaisyah.ac.id/index.php/eja

\title{
TEPUNG LABU KUNING (CUCURBITA MOSCHATA) MENURUNKAN KADAR GLUKOSA DARAH TIKUS MODEL SINDROMA METABOLIK
}

\author{
Diah Wahyuni \\ Program S1 Keperawatan STIKes Aisyah Pringsewu \\ Jl. A. Yani Tambahrejo, Gadingrejo, Pringsewu, 08993557355 \\ Email: aurumdyah329@gmail.com
}

\begin{abstract}
ABSTRAK
Diet tinggi lemak dan fruktosa dapat menginisiasi terjadinya sindroma metabolik, diantaranya dislipidemia, hiperglikemia, dan resistensi insulin. Labu kuning dengan varietas Cucurbita Moschata diketahui memiliki kadar karotenoid yang tinggi, terutama $\alpha$ dan $\beta$-karoten, $\beta$-criptoxanthina, lutein, dan zeaxanthin. Penelitian ini menggunakan metode quasi eksperimental dengan rancangan post test only group design menggunakan tikus Sprague Dawley kedalam 5 kelompok (Kelompok kontrol normal : tikus sehat; Kelompok kontrol hiperglikemia: diet tinggi lemak \& fruktosa (DTLF) ; Kelompok tepung labu kuning 0,16g/200g BB: DTLF + tepung labu kuning 0,16g/200g BB; Kelompok tepung labu kuning 0,32g/200g BB: DTLF + tepung labu kuning 0,32g/200g BB; Kelompok tepung labu kuning 0,64g/200g BB: DTLF + tepung labu kuning 0,64g/200g BB). Pemberian diet tinggi lemak \& fruktosa (DTLF) dilakukan selama 25 hari berturut-turut, selanjutnya dilakukan pemeriksaan kadar glukosa darah. Dilanjutkan pemberian tepung labu kuning dilakukan selama 4 minggu. Data dianalisis dengan uji parametrik yaitu one-way ANOVA dan uji t berpasangan dengan nilai probabilitas $p<0,05$. Hasil uji oneway ANOVA terhadap delta kadar GDP menunjukkan perbedaan yang bermakna antar kelompok $(p<0,05)$, dan hasil uji post hoc didapatkan bahwa delta kadar GDP K3, K4, K5, dan K2 berbeda secara bermakna $p<0,05$. Hasil uji T berpasangan menunjukkan bahwa kadar GDP K2, K3, K4, dan K5 menunjukkan perbedaan yang bermakna setelah induksi DTLF dan setelah intervensi tepung labu kuning, sehingga dapat disimpulkan bahwa intervensi tepung labu kuning dapat menurunkan kadar GDP.
\end{abstract}

Kata kunci : Sindroma metabolik, kadar glukosa darah, labu kuning, karotenoid.

\section{YELLOW PUMPKIN POWDER (CUCURBITA MOSCHATA) DECREASED RATS BLOOD GLUCOSE OF METABOLIC SYNDROME MODELS}

\begin{abstract}
High-fat and fructose diet which lasts longer be considered as a factor in the initiation of metabolic syndrome, likes dyslipidemia, hyperglycemia, and insulin resistance. Pumpkins with varieties Cucurbita Moschata is known have high levels of carotenoids, especially $\alpha \& \beta$-carotene, $\beta$-criptoxanthina, lutein, and zeaxanthin. This study used quasi experimental with post test only control group design. Twenty five male Sprague Dawley rats were induced by induced high fat and fructose diet. Rats were randomly divided into five groups: (1) normal control rats group, (2) hyperglicemia control rats groups, (3) HFFD rats receive powder pumpkin 0,16g/200g weight, (4) HFFD rats receive powder pumpkin 0,32g/200g weight, and (5) HFFD rats receive powder pumpkin $0,64 \mathrm{~g} / 200 \mathrm{~g}$ weight. HFFD was given for 25 days and continued pumpkin powder was given for 28 days. Blood glucose levels were analyzed using glucose oxidase p-aminophenazone (GOD-PAP) method. Expression of IRS1 genes were estimated using real time polymerase chain reaction (RT-PCR). Data analysis was performed with One way ANOVA/Post Hoc test and dependent t-test with significance level of 0.05. The oneway ANOVA test results on the delta of GDP levels showed significant differences between groups $(p<0.05)$, and post hoc test results showed that the delta of $K 3, K 4, K 5$ and $K 2$ GDP differed significantly by $p<0.05$. Paired T-test results showed that the GDP of K2,K3,K4, and K5 showed significant differences after DTLF induction and after intervention of the pumpkin powder, so it can be concluded that the intervention of the pumpkin powder may decrease the GDP level.
\end{abstract}

Keyword : Metabolic syndrome, blood glucose, cucurbita moschata, carotenoid.

How to Cite: Wahyuni, Diah. (2017). Tepung Labu Kuning (Cucurbita Moschata) Menurunkan Kadar Glukosa Darah Tikus Model Sindroma Metabolik. Aisyah: Jurnal Ilmu Kesehatan. 2 (1), 11 - 16. 


\section{Aisyah: Jurnal Ilmu Kesehatan 2 (1) 2017, - 12}

Diah Wahyuni

\section{PENDAHULUAN}

Kelebihan asupan makanan berupa lemak dan gula berperan penting terjadinya gangguan metabolisme. Secara khusus, asupan tinggi lemak jenuh dan gula sederhana dianggap sebagai faktor risiko yang mengawali sindrom metabolik (Aude, Y.W., et al. 2004), termasuk kondisi dislipidemia aterogenik, resistensi insulin (Grundy, S.M., et al. 2002), obesitas sentral, tekanan darah tinggi, dan keadaan inflamasi sistemik (Aude, Y.W., et al. 2004). Konsumsi diet tinggi lemak dan fruktosa yang berlangsung lama akan menginduksi keadaan proinflamasi dan menyebabkan kelainan pada jalur sinyal insulin (Coate, K.C., et al. 2010). Peningkatan asam lemak bebas dapat menyebabkan stres oksidatif karena meningkatnya mitokondria uncoupling (Wojtczak, L., et al. 1993 and Carlsson, C., et al. 1999) sehingga terjadi peningkatan produksi ROS. Stres oksidatif akan menyebabkan aktivasi jalur sinyal sensitifstres yang selanjutnya akan memperburuk sekresi dan aktivitas insulin, yang akhirnya menyebabkan terjadinya diabetes melitus tipe 2. Stres oksidatif yang dihasilkan dari peningkatan produksi ROS berperan penting dalam patogenesis komplikasi akhir diabetes (Brownlee, M., 2001).

Pada kondisi resistensi insulin terjadi gangguan sinyal transduksi insulin yang melibatkan dua jalur utama yaitu phosphatidilinositol 3 kinase (PI3K) dan p38 mitogen activated protein kinase (MAPK). Kerja insulin dalam merangsang ambilan glukosa di otot skelet dan jaringan adiposa dimediasi oleh jalur sinyal insulin yang tergantung PI3K, yang melibatkan insulin receptor substrat-1 (IRS-1)(Kim, Y.I., et al. 2006)

Pencegahan dan penanganan stres oksidatif yang timbul karena produksi ROS dapat dilakukan melalui konsumsi bahan makanan yang mengandung antioksidan. Beberapa varietas labu kuning seperti $C$. moschata, C. maxima dan C. pepo, telah diketahui memiliki kadar karotenoid yang tinggi, terutama $\alpha$ dan $\beta$-karoten, $\beta$ criptoxanthina, lutein dan zeaxanthin (Rodriguez., et al., 2008). Pemberian tepung labu kuning pada tikus diabetik selama 4 minggu secara signifikan menurunkan kadar insulin dan glukosa darah dibandingkan dengan kelompok control (Sedigheh.A., et al. 2011). Karoten diketahui sebagai peredam singlet oxygen $\left({ }^{1} \mathrm{O}_{2}\right)$ dan scavenger untuk reactive oxygen spesies (ROS) yang potensial. Konsumsi antioksidan seperti karotenoid, polifenol, dan tocopherol dapat mencegah stress oksidatif (Tourniaire, F., et al, 2009).

Berdasarkan uraian di atas peneliti berasumsi karotenoid dari tepung labu kuning yang dapat menurunkan stres oksidatif, secara tidak langsung mengurangi kondisi hiperglikemia dan resistensi insulin, yang pada akhirnya akan mencegah komplikasi awal terjadinya sindroma metabolik. Oleh karena itu, analisis pengaruh potensi antioksidan (karotenoid) pada tepung labu kuning ( $C$. moschata) terhadap kadar glukosa darah perlu dilakukan. Pemeriksaan tersebut dapat dilakukan pada tikus yang diinduksi dengan diet tinggi lemak dan fruktosa.

\section{METODE}

Hewan coba yang digunakan adalah tikus Sprague Dawwley jantan (180-200 gram) yang berusia 2 bulan sebanyak 25 ekor yang diperoleh dari Badan Pengawas Obat dan Makanan (BPOM) Jakarta. Tikus dipelihara dalam kandang individual dan disimpan pada kondisi laboratorium (12 jam terang dan 12 jam gelap dalam ruangan yang memiliki suhu $22-25^{\circ} \mathrm{C}$ ). Pakan dan minum diberikan secara ad libithum. Pakan standar dibuat berdasarkan pakan standar AIN-93 $M$ oleh Revees dengan sedikit modifikasi. Pakan standar memiliki komposisi sebagai berikut $24 \%$ casein, DLMethionie $0.30 \%$, cornstarch $61 \%$, vitamin mix $1 \%$, mineral mix $3.5 \%$, choline chloride $0.2 \%$, alpha cell diganti agar-agar 


\section{Aisyah: Jurnal Ilmu Kesehatan 2 (1) 2017, - 13}

Diah Wahyuni

5\%, and corn oil 5\% (Reeves, PG., et al. 1993). Penelitian ini telah disetujui oleh Komite Etik Fakultas Kedokteran, Universitas Gadjah Mada (Ref: $\mathrm{KE} / \mathrm{FK} / 665 / \mathrm{EC})$.

\section{Induksi Diet Tinggi Lemak dan Fruktosa}

Induksi diet tinggi lemak dan fruktosa diberikan selama 25 hari secara ad libithum. Pakan diet tinggi lemak dan fruktosa yang mengacu pada Ble-Castillo dan Tranchida dengan sedikit modifikasi. Pakan diet tinggi lemak dan fruktosa memiliki komposisi sebagai berikut 254,1g casein, cornstarch $305 \mathrm{~g}$, vitamin \& mineral mix $15 \mathrm{~g}$, lemak putih $364,5 \mathrm{~g}$, corn oil $11,1 \mathrm{~g}$, dan fruktosa 61,7g (Tranchida,F., et al. 2012, and BleCastillo,J.L., et al. 2012). Hiperglikemia dikonfirmasi dengan peningkatan kadar glukosa darah puasa $>126 \mathrm{mg} / \mathrm{dL}$ yang diukur pada hari ke-25 setelah induksi. Tikus yang hiperglikemia digunakan sebagai hewan model pada penelitian ini.

\section{Pembuatan Tepung Labu Kuning}

Buah labu kuning dikupas kulitnya dan dibuang bijinya, kemudian dicuci bersih dan dipotong-potong kecil. Setelah itu buahnya di blender sampai halus. Hasil blender dimasukkan ke dalam freeze dryer selama $3 \times 24$ jam, hingga terbentuk tepung labu kuning.

\section{Desain Penelitian}

Penelitian ini menggunakan rancangan pre post test only control group. Hewan coba dikelompokkan secara acak dalam 5 kelompok yang terdiri dari 5 ekor tikus/kelompok, yaitu: (1) kelompok tikus kontrol normal yang diberi pakan standard dan air minum, (2) kelompok tikus kontrol hiperglikemia yang diinduksi diet tinggi lemak dan fruktosa serta air minum, (3) kelompok tikus hiperglikemia yang diberi tepung labu kuning $(0,16 \mathrm{~g} / 200 \mathrm{gBB} / \mathrm{ming} g \mathrm{u}$ per sondase), (4) kelompok tikus hiperglikemia yang diberi tepung labu kunig $(0,32 \mathrm{~g} / 200 \mathrm{gBB} /$ minggu per sondase), dan (5) kelompok tikus hiperglikemia yang diberi tepung labu kunig
$(0,64 \mathrm{~g} / 200 \mathrm{gBB} / \mathrm{minggu}$ per sondase $)$. Semua tepung labu kuning diberikan selama 28 hari. Berat badan tikus diukur setiap minggu. Sampel darah diambil dari vena retro-orbitalis untuk pemeriksaan kadar glukosa darah puasa.

\section{HASIL DAN PEMBAHASAN}

Subjek penelitian ini menggunakan hewan coba yaitu tikus jantan galur Sprague Dawley (Rattus novergicus) umur 8 minggu dengan berat badan antara 180-200 gram. Tikus dipilih sebagai hewan coba karena lebih mudah dikontrol dari segi asupan pakan sehingga dapat memperkecil terjadinya bias saat penelitian. Pemilihan jenis kelamin jantan karena tidak terpengaruh secara hormonal seperti tikus betina.

Berat badan tikus dari hasil pengukuran setiap minggu selama empat minggu intervensi tepung labu kuning masing-masing kelompok mengalami peningkatan berat badan yang signifikan. Perubahan rerata berat badan tikus selama perlakuan seperti terlihat pada Gambar 1. Hasil penelitian menunjukkan bahwa semua kelompok tikus mengalami peningkatan berat badan dari $264,40 \pm 23,32$ gram menjadi $314,20 \pm 45,97$ gram. Tikus hiperglikemia yaitu $258,80 \pm 24,24$ gram menjadi 293,60 $\pm 25,69$ gram, kelompok tikus hiperglikemia yang diberi dosis tepung labu kuning $0,16 \mathrm{~g} / 200 \mathrm{~g}$ BB yaitu $267,00 \pm 23,30$ gram menjadi $340,00 \pm$ 32,98 gram, kelompok tikus hiperglikemia yang diberi dosis tepung labu kuning $0,32 \mathrm{~g} / 200 \mathrm{~g}$ BB yaitu $256,20 \pm 27,97$ gram menjadi $297,00 \pm 31,77$ gram, dan kelompok tikus hiperglikemia yang diberi dosis tepung labu kuning $0,64 \mathrm{~g} / 200 \mathrm{~g}$ BB yaitu $280,80 \pm 19,31$ gram menjadi 312,60 $\pm 45,29$ gram. 


\section{Aisyah: Jurnal Ilmu Kesehatan 2 (1) 2017, - 14}

Diah Wahyuni

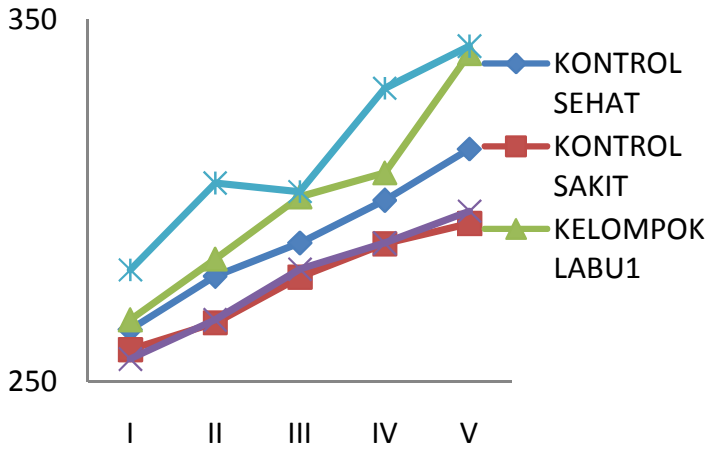

Gambar 1. Perubahan rerata berat badan tikus selama 28 hari perlakuan

Peningkatan berat badan tikus dapat disebabkan oleh faktor pertumbuhan dan asupan pakan selama penelitian. Tikus yang diinduksi diet tinggi lemak dan fruktosa umumnya akan mengalami kenaikan berat badan lebih tinggi dibandingkan dengan tikus normal. Tranchida., et al. melaporkan bahwa tikus yang diinduksi diet tinggi fruktosa dan lemak jenuh selama 30 minggu mengalami kenaikan berat badan relatif sebesar $11 \%$ terhadap kelompok kontrol. Peningkatan berat badan diduga karena diet tinggi fruktosa dan lemak ini dapat memicu sintesis gen-gen lipogenik yang menginduksi terjadinya lipogenesis yang akan meningkatkan produksi trigliserida dan kolesterol sehingga terjadi peningkatan lemak viseral dan berat badan.

Pada penelitian ini, tikus yang diinduksi diet tinggi lemak dan fruktosa memiliki kadar Glukosa Darah Puasa (GDP) rata-rata $130-140 \mathrm{mg} / \mathrm{dL}$. Perubahan kadar GDP tikus setelah induksi diet tinggi lemak dan fruktosa tetapi belum intervensi dan setelah intervensi tepung labu kuning.

Tabel 1

Rerata kadar glukosa darah puasa (GDP) tikus (mg/dL) setelah induksi dan setelah intervensi

\begin{tabular}{|c|c|c|c|c|}
\hline Kelompok & $\begin{array}{c}\text { Setelah Induksi } \\
\text { DTLF }\end{array}$ & $\begin{array}{c}\text { Setelah } \\
\text { Intervensi }\end{array}$ & $\Delta G D P$ & $\mathbf{p}$ \\
\hline Normal (K1) & $78,24 \pm 1,24$ & $78,20 \pm 1,08$ & $-0,04 \pm 0,57$ & 0,888 \\
\hline Hiperglikemia (K2) & $135,84 \pm 2,34$ & $137,19 \pm 2,17$ & $+1,35 \pm 0,87^{\mathrm{a}}$ & $0,025^{+}$ \\
\hline Tepung labu kuning $0,16 \mathrm{~g}(\mathrm{~K} 3)$ & $138,16 \pm 1,19$ & $117,81 \pm 1,41$ & $-20,35 \pm 0,59^{b}$ & $0,000^{+}$ \\
\hline Tepung labu kuning $0,32 \mathrm{~g}(\mathrm{~K} 4)$ & $144,48 \pm 4,62$ & $105,70 \pm 4,17$ & $-38,78 \pm 1,08^{b}$ & $0,000^{+}$ \\
\hline Tepung labu kuning 0,64g (K5) & $137,36 \pm 2,07$ & $86,02 \pm 2,00$ & $-51,34 \pm 0,45^{\mathrm{b}}$ & $0,000^{+}$ \\
\hline $\mathrm{p}^{*}$ & & & $0,000^{++}$ & \\
\hline
\end{tabular}

Pada pemeriksaan GDP diketahui bahwa kelompok yang diinduksi diet tinggi lemak dan fruktosa (K2=hiperglikemia; $\mathrm{K} 3=$ tepung labu kuning $0,16 \mathrm{~g}$; K4=tepung labu kuning $0,32 \mathrm{~g} ; \mathrm{K} 5=$ tepung labu kuning 0,64g) memiliki kadar GDP jauh lebih tinggi jika dibandingkan dengan tikus sehat $(\mathrm{K} 1=$ Sehat). Hal ini sejalan dengan penelitian Tranchida., et al dimana kadar insulin plasma dan glukosa puasa juga signifikan lebih tinggi pada kelompok diet tinggi fruktosa dan lemak jenuh selama durasi diet. Pemberian induksi diet tinggi lemak dan fruktosa selama 25 hari kemudian dilanjutkan dengan intervensi tepung labu kuning yang diberikan selama 28 hari, memberikan pengaruh terhadap glukosa darah. Rerata delta GDP antara kelompok intervensi $(\mathrm{K} 3=0,16 \mathrm{~g}, \mathrm{~K} 4=0,32$ $\mathrm{g}$, dan $\mathrm{K} 5=0,64 \mathrm{~g})$ dengan kelompok hiperglikemia berbeda bermakna. Hal ini sejalan dengan yang dilaporkan Sedigheh et al. bahwa pemberian tepung labu kuning menurunkan kadar glukosa secara signifikan. Tikus diabetes dibandingkan 
Aisyah: Jurnal Ilmu Kesehatan 2 (1) 2017, - 15

Diah Wahyuni

yang terdapat pada tikus kelompok kontrol tanpa perlakuan. 


\section{Aisyah: Jurnal Ilmu Kesehatan 2 (1) 2017, - 16 \\ Diah Wahyuni}

\section{DAFTAR PUSTAKA}

Aude, Y. W., Mego, P., Mehta, J. L. Metabolic Syndrome: Dietary Interventions. (2004). Curr Opin Cardiol. 19: 473-479.

Ble-Castillo, J. L., Aparicio-Trapala, M. A., Juarez-Rojop, I. E., Torres-Lopez, J. E., Mendez, J. D., Aguilar-Mariscal, H., Olvera-Hernandez, V., PalmaCordova, L. C., Diaz-Zagoya, J. C. (2012). Differential Effect of HighCarbohydrate and High-Fat Diet Composition on Metabolic Control and Insulin Resistance in Normal Rats. Int J Environ Res. 9: 16631676.

Brownlee, M. (2001). Biochemistry and molecular cell biology of diabetic complications. Nature. 414: 813820.

Carlsson, C., Borg, L. A., Welsh, N. (1999). Sodium Palmitate Induces Partial Mitochondrial Uncoupling And Reactive Oxygen Species In Rat Pancreatic Islets In Vitro. Endocrinology. 140: 3422-3428.

Coate, K. C., Scott, M., Farmer, B., Moore. M. C., Smith, M., Roop, J., Neal, D. W., Williams, P., Cherrington, A. D. (2010). Chronic consumption of a high-fat/high-fructose diet renders the liver incapable of net hepatic glucose uptake. Am $J$ Physiol Endocrinol Metab. 299: 887-898.

Grundy, S. M., Abate, N., and Chandalia, M. (2002). Diet Composition and The Metabolic Syndrome: What Is The Optimal Fat Intake. Am Med J. 30: 113 .

Kim, Y. I., Lee, F. N., Choi, W. S. (2006). Insulin Regulation of Sceletal Muscle PDK4 mRNA Expression Is Impaired in Acute Insulin Resistant State. Diabetes. 55(8): 2311-2317.
Reeves, PG., Neilsen, FH., and Fahey, JR. (1993). AIN-93 Purified Diets for Laboratory Rodents: Final Report of The American Institute of Nutrition Ad Hoc Writing Committee on the Formulation of the AIN-76A Rodent Diet. J Nutr. 123(11): 1939-51.

Rodriguez-Amaya, D. B., Kimura, M., Godoy, H. T., and Amaya-Farfan, J. (2008). Updated Brazilian Database on Food Carotenoids: Factors Affecting Carotenoids Composition. J Food Compost Anal. 21: 445-463.

Sedigheh. A., Jamal. M.S., Mahbubeh. S., Somayeh. K., Mahmoud. R, Azadeh. A., and Fatemeh. S. (2011). Hypoglycaemic and Hypolipidemic Effects of Pumpkin (Cucurbita Pepo L.) on Alloxan-Induced Diabetic Rats. J Pharm Pharm. 23: 26202626.

Tourniaire, F., Gouranton,E., Von Lintig, J., Keijer, J., Luisa Bonet,M., Amengual, J., Lietz, G., and Landrier, J. F. (2009). Beta-carotene conversion products and their effects on adipose tissue. Genes Nutr. 3: 179-187.

Tranchida, F., Tchiakpe, L., Rakotoniaina, Z., Deyris, V., Ravion, O., Hiol, A. (2012). Long-term High Fructose and Saturated Fat Diet Affects Plasma Fatty Acid Profile In Rats. Biomed \& Biotechnol. 13(4): 307317

Wojtczak, L. \& Schonfeld, P. (1993). Effect of Fatty Acids on Energy Coupling Processes in Mitochondria. Biochim Biophys Acta. 1183: 41-57. 